BIBLIOTIKA : Jurnal Kajian Perpustakaan dan Informasi

Volume 2 Nomor 2, 2018

Journal homepage : http://journal2.um.ac.id/index.php/bibliotika

\title{
KEBUTUHAN INFORMASI DAN UPAYA PEMENUHAN KEBUTUHAN INFORMASI PADA KOMUNITAS AKAR TULI
}

Tri Rahma Kusuma Wardani, , Heri Suwignyo, Dwi Novita Ernaningsih

Program Studi S1 Ilmu Perpustakaan Universitas Negeri Malang

\begin{tabular}{|c|c|}
\hline $\begin{array}{l}\text { A R T I C L E } \\
\text { I N F O }\end{array}$ & A B S T RACT \\
\hline $\begin{array}{l}\text { Article history: } \\
\text { Received: } 10 \text { Oct } 2017 \\
\text { Accepted: } 30 \text { Nop } 2017 \\
\text { Published: } 15 \text { Nov } 2018 \\
\text { Keyword: } \\
\text { kebutuhan informasi, } \\
\text { upaya pemenuhan } \\
\text { kebutuhan informasi, } \\
\text { komunitas Akar Tuli, tuli, } \\
\text { tunarungu }\end{array}$ & $\begin{array}{l}\text { Penelitian ini bertujuan untuk mendeskripsikan kebutuhan informasi } \\
\text { dan upaya pemenuhan kebutuhan informasi anggota komunitas Akar } \\
\text { Tuli Malang. Hal tersebut ditinjau dari faktor yang mendorong } \\
\text { kebutuhan informasi anggota komunitas. Metode penelitian ini } \\
\text { menggunakan metode studi kasus dengan pendekatan kualitatif. } \\
\text { Teknik pengumpulan data dilakukan dengan observasi, wawancara, } \\
\text { dan telaah dokumen. Hasil penelitian menunjukkan bahwa } \\
\text { kebutuhan informasi anggota komunitas didorong oleh sepuluh } \\
\text { faktor. Selain sepuluh faktor tersebut, kebutuhan informasi anggota } \\
\text { komunitas juga dipengaruhi oleh isi informasi yang disertai dengan } \\
\text { gambar untuk memudahkan mereka dalam menerjemahkan, dan } \\
\text { memahami informasi yang diperoleh. Upaya pemenuhan kebutuhan } \\
\text { informasi anggota komunitas dilakukan dengan beberapa cara, yakni } \\
\text { pencarian informasi melalui manusia atau bertanya kepada orang } \\
\text { lain, pencarian informasi melalui dokumen, pencarian informasi } \\
\text { melalui gawai atau secara online, dan membaca bibir lawan bicara. }\end{array}$ \\
\hline
\end{tabular}

\section{PENDAHULUAN}

Dalam memenuhi hak informasi yang terdiri dari menerima, memberi, dan memanfaatkan informasi dilatarbelakangi oleh kebutuhan informasi. Menurut Nicholas (2000:93110) kebutuhan informasi dipengaruhi oleh sepuluh faktor, terdiri dari faktor jenis pekerjaan seseorang, faktor kebudayaan tempat orang tersebut tinggal, faktor kepribadian (dalam diri), faktor tingkat kesadaran seseorang akan kebutuhan informasinya, faktor jenis kelamin, faktor usia, faktor ketersediaan waktu dalam proses pencarian informasi, faktor akses informasi, faktor biaya yang ditanggung selama melakukan pencarian informasi yang dibutuhkan, dan faktor informasi yang berlebih (overload information).

Terjadinya kebutuhan informasi dapat diketahui bahwa informasi adalah untuk semua orang bagi yang membutuhkan (Safii, 2019). Informasi tersebut tersedia untuk semua orang atau untuk orang tertentu yang sesuai dengan kebutuhannya. Hal tersebut dapat dikatakan bahwa

\footnotetext{
* Corresponding author.

E-mail addresses: kusuma.rahma.kr@gmail.com (Tri Rahma Kusuma Wardani)
}

ISSN : 2579-3802 (Online) - BIBLIOTIKA : Jurnal Kajian Perpustakaan dan Informasi is licensed under Creative Commons Attribution-ShareAlike 4.0 International License (http://creativecommons.org/licenses/BY/4.0/). 
informasi adalah milik semua orang, tidak terkecuali para penyandang disabilitas khususnya tunarungu. Penyandang tunarungu pun memiliki hak atas informasi yang tersedia.

Ketersediaan informasi bagi penyandang tunarungu sangat terbatas. Hal tersebut dapat dilihat dari informasi tercetak seperti buku dan jurnal yang terdapat di perpustakaan. Sedikit koleksi perpustakaan dalam bentuk cetak yang dapat memenuhi kebutuhan informasi penyandang tunarungu. Koleksi perpustakaan yang dikhususkan untuk penyandang disabilitas saat ini adalah untuk penyandang tunanetra. Hal tersebut membuktikan bahwa informasi untuk penyandang tunarungu kurang diperhatikan.

Penelitian mengenai kebutuhan informasi telah banyak dilakukan, seperti penelitian yang telah dilakukan oleh Retty Dina Lestari (2012) tentang kebutuhan informasi penyandang tunanetra, menunjukkan bahwa individu penyandang disabilitas membutuhkan informasi untuk menunjang kebutuhan kehidupan sehari-hari, mulai dari pendidikan hingga hobi mereka. Selain itu penelitian serupa tentang kebutuhan informasi yang dilakukan oleh Henny Setia Ningsih (2012) mengenai kebutuhan informasi remaja kota, yang menunjukkan bahwa penyandang disabilitas dalam memenuhi kebutuhan informasi mereka dapat dengan menggunakan sumber informasi, seperti media cetak, media elektronik, dan sumber informasi manusia. Tujuan penelitian ini adalah untuk mendeskripsikan kebutuhan informasi dan upaya pemenuhan kebutuhan informasi penyandang tunarungu atau tuli yang bergabung menjadi anggota di komunitas Akar Tuli Malang.

\section{METODE PENELITIAN}

Pendekatan penelitian yang digunakan adalah pendekatan kualitatif dengan metode studi kasus. Penelitian kualitatif adalah penelitian yang memiliki maksud untuk memahami fenomena yang terjadi atau yang dialami oleh subjek penelitian (Indranata, 2008:3-4). Penelitian dengan metode studi kasus digunakan untuk mencermati individu atau kelompok secara mendalam (Arikunto, 2013:185). Sumber data dalam penelitian ini diperoleh melalui keterangan dari beberapa informan yang menjadi anggota komunitas dan relawan komunitas Akar Tuli, yaitu ketua komunitas, ketua divisi, dan relawan komunitas. Sumber data dalam penelitian berupa sumber data primer dan sumber data sekunder. Teknik pengumpulan data yang dilakukan dalam penelitian ini adalah wawancara, observasi atau pengamatan, dan telaah dokumen

Teknik analisis data yang digunakan dalam penelitian ini adalah teknik analisis interaktif. Langkah-langkah teknik analisis data dalam penelitian ada enam (Creswell, 2016), yakni 1) mengolah dan mempersiapkan data untuk dianalisis; 2) membaca seluruh data dilakukan untuk memaknai informasi dan data yang didapatkan dari informan secara keseluruhan; 3) memberi kode data dilakukan untuk mempermudah peneliti dalam melakukan analisis data yang didapat; 4) tema-deskripsi dilakukan untuk mengelompokkan informasi atau data ke dalam tema-tema berdasarkan topik yang sama; 5) penyajian data, data hasil yang disajikan berdasarkan temuantemuan di lapang yang diperoleh dari hasil observasi, wawancara, dan telaah dokumen; 6) interpretasi data, peneliti menginterpretasi data dengan membahasnya menggunakan teori-teori yang terkait.

\section{HASIL PENELITIAN}

\section{Kebutuhan Informasi Anggota Komunitas Akar Tuli}

Anggota komunitas sebagai mahasiswa membutuhkan informasi terkait perkuliahan. Kebutuhan informasi anggota komunitas dalam perkuliahan sama seperti mahasiswa pada umumnya, yakni informasi yang berkaitan dengan matakuliah yang diambil. Namun demikian, terdapat perbedaan bagi penyandang tunarungu, yakni kebutuhan mendapatkan pendamping saat perkuliahan berlangsung. Dalam memecahkan suatu masalah anggota komunitas harus mengetahui terlebih dahulu penyebab masalah tersebut. Dalam mencari solusi untuk memecahkan permasalahan yang dihadapi, anggota Akar Tuli juga mendiskusikan terlebih dahulu permasalahan tersebut dengan yang lain, baik anggota maupun relawan komunitas. 
Anggota komunitas dalam melakukan pencarian informasi menggunakan fasilitas pencarian yang tersedia di internet, seperti google. Alernatif pencarian informasi yang lain adalah dengan bertanya kepada teman. Pemahaman dalam menerima informasi sangat penting. Penyandang tunarungu akan memahami terlebih dahulu isi dari informasi tersebut kemudian melakukan evaluasi. Anggota komunitas juga melakukan pengelompokkan informasi berdasarkan tema informasi agar tidak terjadi kesalahpahaman dalam memahami informasi tersebut.

Anggota komunitas sadar bahwa mereka membutuhkan informasi, dan mereka cenderung mencari informasi apapun untuk menambah pengetahuan mereka, namun tetap menyaring informasi yang diperoleh dengan bertanya kepada teman. Berdasarkan jenis kelamin, anggota komunitas laki-laki lebih sering mencari informasi tentang hobi mereka, sedangkan yang perempuan cenderung mencari informasi tentang pernikahan dan agama. Informasi lain yang dibutuhkan anggota komunitas adalah informasi tentang lowongan pekerjaan, sebab usia anggota komunitas kini berkisar 23-25 tahun.

Dalam hal waktu yang dibutuhkan anggota komunitas untuk pencarian informasi tidak tentu, bahkan dapat berhari-hari. Anggota komunitas cenderung menggunakan gawai atau pencarian informasi secara online, sebab hal tersebut memudahkan mereka dalam mencari informasi yang sesuai dengan kebutuhan mereka. Kebutuhan informasi anggota komunitas Akar Tuli memiliki ciri tersendiri, yakni informasi yang disertai dengan gambar. Dalam hal kebutuhan informasi, anggota komunitas memerlukan pendamping atau penerjemah untuk menerjemahkan informasi yang didapat, sebab informasi yang berupa teks saja dapat membingungkan anggota komunitas dalam memahami isi informasi tersebut.

\section{Upaya Pemenuhan Kebutuhan Informasi Anggota Komunitas Akar Tuli}

Anggota komunitas melakukan pencarian informasi melalui manusia dengan cara bertanya kepada teman yang dipercaya atau pendamping. Hal tersebut dilakukan karena teman atau pendamping dapat menggunakan bahasa isyarat sebagai bahasa utama penyandang tunarungu. pencarian informasi melalui teman sering dilakukan. Hal tersebut dikarenakan mereka dapat bercerita dan bertanya tentang banyak hal kepada teman. Berdiskusi dengan teman saat melakukan pencarian informasi dari teman dapat dilakukan sekaligus.Pencarian informasi melalui dokumen adalah upaya lain untuk memenuhi kebutuhan informasi anggota komunitas. Anggota komunitas melakukan pencarian informasi dengan menggunakan media tercetak seperti majalah, koran, buku sebab hal tersebut mudah untuk dilakukan.

\section{PEMBAHASAN}

\section{Kebutuhan Informasi Anggota Komunitas Akar Tuli}

Kebutuhan informasi akan muncul apabila terdapat faktor yang mendorong seseorang untuk melakukan pencarian informasi. Menurut Nicholas (2000) terdapat sepuluh faktor dalam kebutuhan informasi, yakni, dari faktor pekerjaan, faktor kebudayaan, faktor kepribadian, faktor sadar akan informasi, faktor jenis kelamin, faktor usia, faktor ketersediaan waktu, faktor akses, faktor biaya, dan faktor informasi berlebih.

\section{Faktor pekerjaan.}

Dalam dunia pekerjaan seorang pekerja akan membutuhkan informasi terkait dengan pekerjaan yang digeluti. Pekerjaan tidak hanya dalam lingkup seseorang yang bekerja di sebuah kantor, namun seorang mahasiswa juga dianggap pekerja. Namun demikian, mahasiswa adalah status pekerjaan. Dalam penelilitan ini faktor pekerjaan yang terdapat dalam komunitas Akar Tuli adalah status pekerjaan anggota, yakni mahasiswa. Sebagai mahasiswa, informasi yang dibutuhkan anggota komunitas adalah informasi terkait perkuliahan, mulai dari mata kuliah yang akan diambil, dosen pengampu, hingga tempat perkuliahan berlangsung. Dalam perkuliahan anggota komunitas atau tuli wajib didampingi oleh pendamping atau penerjemah agar mereka dapat 
menerima informasi yang disampaikan oleh dosen maupun teman lain saat perkuliahan berlangsung.

Faktor kebudayaan.

Dalam memecahkan suatu masalah, Indonesia memiliki cara tersendiri untuk mencari solusi tersebut, yakni dengan bermusyawarah. Dalam bermusyawarah anggota komunitas juga mengajak para relawan komunitas sebagai penerjemah suatu informasi yang didapatkan. Para relawan dalam membantu anggota komunitas harus bisa menyampaikan informasi yang dapat dipahami oleh anggota komunitas (Rahmala, Suwignyo, \& Kurniawan, 2018).

Faktor kepribadian.

Dalam kepribadian seseorang dipengaruhi oleh empat hal (Nicholas, 2000) antara lain ketekunan, ketelitian, keteraturan, dan cara seseorang menerima informasi. Anggota komunitas dalam melakukan pencarian informasi juga menggunakan alternatif pencarian lain. Dalam hal ini alternatif pencarian yang dilakukan apabila pencarian sebelumnya tidak berhasil adalah dengan melakukan pencarian informasi secara online, atau bertanya kepada teman. Dalam hal ketelitian, anggota komunitas juga mengevaluasi informasi yang didapat. Apabila terdapat kesalahan pada informasi yang diperoleh akan langsung ditanyakan kepada teman sehingga mereka dapat memperbaiki informasi yang salah tersebut.

Informasi yang diperoleh akan dipahami terlebih dahulu oleh anggota komunitas, yang kemudian informasi tersebut dikelompokkan berdasarkan isi informasi tersebut. Informasi yang diperoleh dikelompokkan berdasarkan saran dari teman agar mengetahui bahwa informasi yang diperoleh tersebut memiliki tema yang sama atau berbeda. Dalam menerima informasi yang diperoleh, anggota komunitas akan menanyakan kepada teman dengar atau pendamping atau penerjemah. Hal tersebut dilakukan agar tidak terjadi kesalahpahaman dalam memahami informasi yang didapat.

Faktor sadar akan informasi.

Anggota komunitas memiliki tingkat kesadaran informasi yang cukup tinggi. Hal ini terbukti dari keaktifan mereka dalam bertanya kepada teman atau penerjemah atau pendamping tentang suatu informasi yang didapat. Bantuan tersebut adalah saran dari teman yang lain untuk mengetahui apakah informasi yang diperoleh adalah informasi yang benar atau tidak. Hal tersebut selaras dengan pernyataan Suwarno (2010:44) bahwa informasi memiliki nilai kebenaran, informasi selalu berisi kebenaran dari sebuah kenyataan atau fakta yang ada, apabila informasi yang berisi hoax dipercaya oleh masyarakat, maka dampaknya adalah sama dengan jika informasi tersebut benar.

Faktor jenis kelamin.

Nicholas (2000:99) menyatakan bahwa dalam pencarian informasi wanita lebih jujur daripada pria, wanita tidak segan bertanya kepada seseorang, sedangkan pria lebih memilih untuk tidak bertanya dan mencari informasi tersebut dengan caranya sendiri. Dalam hal ini anggota komunitas (perempuan) tidak memiliki rasa malu saat ingin bertanya kepada teman lain untuk mengetahui suatu informasi yang belum diketahui. Sedangkan anggota komunitas (laki-laki) mencari informasi yang dibutuhkan dengan melakukan pencarian melalui internet, youtube, dan media sosial (Akbar, Martutik, \& Safii, 2018).

Faktor usia.

Usia anggota komunitas dalam penelitian ini rata-rata berada di umur 23-25 tahun. Dalam rentang usia ini informasi yang sering dicari oleh anggota komunitas adalah tentang pekerjaan. Mencari informasi tentang lowongan pekerjaan yang sesuai untuk mereka, dan perusahaan mana yang menampung karyawan disabilitas. kebutuhan informasi mengenai pekerjaan juga disebabkan oleh faktor penyelesaian tahap akhir kuliah. Anggota komunitas kini telah berada pada tahap penyelesaian tugas akhir atau skripsi sehingga informasi yang dibutuhkan saat ini dan dalam rentang usia ini adalah informasi mengenai pekerjaan.

Faktor ketersediaan waktu. 
Anggota komunitas dalam melakukan pencarian informasi tidak memiliki batas waktu tertentu. Waktu yang dibutuhkan dalam mencari suatu informasi cenderung tidak tentu berapa lama. Hal tersebut dikarenakan menunggu waktu yang tepat untuk dapat bertemu dengan teman, atau pendamping. Dalam hal ini, tidak dapat dipastikan berapa lama atau waktu yang dibutuhkan untuk melakukan pencarian informasi, sebab hal tersebut bergantung pada waktu luang masingmasing anggota komunitas dan teman atau pendamping.

Faktor akses.

Peralatan yang sering digunakan oleh anggota komunitas adalah alat elektronik seperti smartphone, laptop, komputer, dan alat manusia. Komunitas Akar Tuli adalah komunitas yang bergerak dibidang sosial sehingga informasi yang dibutuhkan tidak sebatas mengenai perkuliahan saja. Oleh sebab itu, anggota komunitas memerlukan peralatan yang mendukung untuk melakukan pencarian informasi. Peralatan elektronik seperti smartphone, laptop, komputer dibutuhkan anggota komunitas untuk mencari informasi sebab anggota komunitas sering melakukan pencarian informasi melalui peralatan tersebut. pencarian informasi melalui internet dengan menggunakan peralatan eletronik tersebut cukup efisien. Namun demikian alat akses lain yang digunakan anggota komunitas adalah manusia. Anggota komunitas juga sering menggunakan alat akses manusia sebab mereka dapat berdiskusi sekaligus kepada teman tentang suatu informasi tertentu.

Faktor biaya.

Seseorang dapat memenuhi kebutuhan informasi mereka berdasarkan biaya yang dikeluarkan pula. Hal tersebut berpengaruh terhadap seberapa jauh dan seberapa banyak informasi yang diperoleh. Anggota komunitas dalam memenuhi kebutuhan informasi juga memerhatikan seberapa biaya yang akan dikeluarkan untuk sebuah informasi. Pencarian informasi saat ini lebih dimudahkan dan tidak terlalu memakan biaya banyak. Hal tersebut dapat dilihat dari biaya yang murah untuk paket data, karena anggota komunitas dalam melakukan pencarian informasi melalui internet sehingga biaya yang dikerluarkan tidak terlalu banyak.

Pada saat ini pemenuhan kebutuhan informasi dapat dicari dengan gratis, yakni dapat dengan memanfaatkan perpustakaan yang tidak memberikan biaya untuk meminjam koleksi. Selain itu dapat pula memanfaatkan fasilitas yang ada secara gratis, seperti wifi gratis, internet corner (internet gratis) yang terdapat di beberapa tempat. Selain itu pencarian informasi secara online atau dengan internet dapat dilakukan di warung internet dengan biaya yang terbilang murah pula. Faktor informasi berlebih.

Informasi yang tersedia di internet saat ini sangat banyak dan beragam. . Nicholas (2000:108) menyatakan bahwa informasi dapat menjadi kebutuhan namun juga dapat menjadi hambatan untuk pemenuhan kebutuhan informasi tersebut. Kelebihan informasi (overload information) juga pernah dirasakan oleh anggota komunitas. Informasi berlebih menghambat proses pencarian informasi sebab terlalu banyak informasi yang tersedia dan membutuhkan waktu yang lama untuk memilah informasi yang dapat digunakan. Pemilihan informasi tersebut membuang banyak waktu bagi anggota komunitas, karena seharusnya hal tersebut tidak terjadi apabila informasi yang tersedia sedikit dan terpercaya.

\section{Upaya Pemenuhan Kebutuhan Informasi Anggota Komunitas Akar Tuli}

Upaya merupakan tindakan atau cara yang dilakukan seseorang untuk memecahkan masalah yang sedang dihadapi. Anggota komunitas Akar Tuli melakukan upaya untuk memenuhi kebutuhan informasinya melalaui beberapa cara. Cara atau upaya yang dilakukan tersebut antara lain dengan melakukan pencarian informasi melalui manusia, pencarian informasi melalui dokumen atau informasi tercetak.

Pencarian informasi melalui manusia.

Pencarian informasi melalui manusia biasanya dilakukan dengan cara bertanya kepada orang lain. Informasi yang terdapat pada manusia adalah pengetahuan dan pengalaman orang tersebut (Safii, 2017). Selaras dengan Wilson (2000:50) yang menyatakan bahwa pengetahuan 
hanya diketahui oleh orang yang tahu, dan pengetahuan yang dimiliki seseorang dapat direkam dan diakses orang lain, informasi tersebut merupakan pengganti pengetahuan yang kurang diketahui.

Pencarian informasi kepada orang lain dilakukan tidak kepada semua orang, hanya kepada orang tertentu saja. Anggota komuntas akan bertanya kepada pendamping atau teman yang dapat menggunakan bahasa isyarat sebagai bahasa utama mereka. Anggota komunitas mencari ilmu pengetahuan dan informasi yang belum diketahui juga melalui teman. Anggota komunitas dapat bercerita dan bertanya tentang banyak hal kepada teman. Hal tersebut dapat menambah pengetahuan aggota komunitas, dan mereka dapat berdiskusi sekaligus saat bertanya kepada teman untuk mencari informasi tertentu.

Pencarian informasi melalui orang lain, dalam hal ini yang dimaksud adalah orang asing atau orang lain yang tidak dapat menggunakan bahasa isyarat sehingga anggota komunitas harus didampingi oleh penerjemah. Anggota komunitas atau tuli harus didampingi oleh orang dengar (dalam artian ini adalah pendamping atau penerjemah) agar mereka dapat memahami informasi yang disampaikan dosen atau teman kuliah saat perkuliahan berlangsung atau orang lain. Seseorang yang dapat menggunakan bahasa isyarat tidaklah banyak. Hal tersebut memunculkan ide bagi komunitas untuk mengadakan kegiatan sosialisasi bahasa isyarat Indonesia (BISINDO) dan pelatihan BISINDO. Pelatihan BISINDO ini bertujuan agar masyarakat dapat menggunakan bahasa isyarat sebagai bahasa utama tuli untuk berkomunikasi. Minimnya pengetahuan masyarakat dan masyarakat yang dapat menggunakan bahasa isyarat merupakan alasan utama pelatian BISINDO ini diadakan.

Berdasarkan hasil wawancara dengan anggota komunitas, penyataan dari anggota komunitas sesuai dengan teori mengenai pencarian informasi dengan menggunakan sumber informasi manusia (Nicholas, 2000). Sumber informasi tersebut adalah teman yang dapat menggunakan bahasa isyarat, pendamping dan/atau penerjemah. Upaya lain yang dilakukan adalah dengan membaca bibir lawan bicara.

Pencarian informasi melalui dokumen.

Pencarian informasi melalui dokumen dilakukan anggota komunitas untuk memenuhi kebutuhan informasi mereka. Dokumen yang dimaksud adalah sumber informasi dalam bentuk cetak, seperti buku, koran, majalah, jurnal dan lain sebagainya. Pencarian informasi melalui beberapa sumber informasi tercetak yang telah disebutkan adalah cara pencarian yang umum dilakukan, oleh sebab itu anggota komunitas dapat melakukan pencarian melalui sumber informasi tersebut.

Meskipun melakukan pencarian informasi melalui dokumen, anggota komunitas lebih sering melakukan pencarian informasi dengan menggunakan gawai atau pencarian informasi secara online. Pencarian informasi secara online lebih dipilh sebab lebih mudah, cepat, dan efisien. Anggota komunitas lebih memilih pencarian informasi melalui google sebab dari pencarian dengan internet tersebut dapat dengan mudah mencari informasi yang disertai dengan gambar. Apabila informasi yang didapat hanyalah sebuah teks, hal tersebut akan menyulitkan anggota komunitas dalam memahami atau memaknai informasi yang didapat.

Kesulitan yang dialami oleh anggota komunitas mengakibatkan terbentuknya ciri informasi yang dibutuhkan oleh mereka. Berbeda dengan individu pada umumnya, anggota komunitas memiliki ciri informasi yang digunakan untuk memenuhi kebutuhan informasinya. Ciri tersebut terdapat pada informasi yang disertai dengan gambar. Gambar yang terdapat dalam sebuah informasi akan memudahkan mereka dalam memahami, memaknai informasi yang dimaksud. Anggota komunitas dalam melakukan pencarian informasi cenderung menggunakan gawai atau alat elektronik seperti telepon genggam atau smartphone, komputer, laptop atau notebook, tablet. Gawai merupakan sarana yang digunakan anggota komunitas dalam melakukan pencarian, sebab beberapa gawai dapat dibawa kemanapun dan tidak terlalu besar ukurannya, seperti smartphone dan tablet (Safii, 2015). 
Hasil dari pencarian informasi dengan menggunakan internet adalah informasi digital atau elektronik, dan terekam. Informasi elektronik tersebut berupa e-book, e-journal, e-newspaper, dan lain sebagainya Suwarno (2010:24). Informasi terekam adalah informasi berupa audio-visual gerak atau gambar bergerak yang diiringi dengan suara (Haryoko, 2009:3). Informasi tersebut dapat ditemukan pada salah satu website yang sering digunakan masyarakat, yakni youtube. Namun demikian pencarian informasi dari youtube juga disertai dengan tulisan atau keterangan sehingga anggota komunitas dapat memahami informasi yang diperoleh dari youtube.

Berdasarkan hasil wawancara dengan anggota komunitas pernyataan dari salah satu anggota selaras atau sesuai dengan teori pencarian informasi melalui dokumen (Nicholas, 2000). Namun demikian, pernyataan dari informan yang lain dan relawan tidak sesuai dengan teori pencarian informasi menurut Nicholas (2000) sebab anggota komunitas dan relawan lebih memilih dan lebih sering melakukan pencarian informasi dengan menggunakan gawai atau pencarian informasi secara online (Moh Safii, Zen, \& Mayesti, 2018). Hal tersebut disebabkan oleh kemudahan dalam melakukan pencarian secara online yang dapat dilakukan kapan saja, dan di mana saja selama tersedia alat untuk akses informasi secara online tersebut.

\section{PENUTUP}

\section{Simpulan}

Kebutuhan informasi anggota komunitas memiliki ciri yang memudahkan merekan dalam memahami informasi yang diperoleh. Ciri informasi tersebut adalah informasi yang dibutuhkan harus disertai dengan gambar. Anggota komunitas mengandalkan visual untuk memahami informasi yang didapat. Anggota komunitas dalam memahami suatu informasi yang berupa teks akan membutuhkan penerjemah atau pendamping untuk menjelaskan isi dari informasi yang diperoleh. Hal tersebut disebabkan oleh kurangnya kosakata yang dimiliki oleh mereka.

Anggota komunitas dalam memenuhi kebutuhan informasi rata-rata melakukan pencarian informasi melalui gawai atau secara online. Pencarian informasi secara online lebih efisien waktu, dan anggota komunitas dapat mengambil informasi yang sesuai dengan kebutuhannya, yakni informasi yang disertai dengan gambar. Upaya lain yang dilakukan anggota komunitas untuk dapat memahami informasi yang disampaikan oleh orang lain adalah dengan membaca bibir lawan bicara.

\section{Saran}

Saran disampaikan berdasarkan hasil simpulan di atas, yaitu ditujukan kepada anggota komunitas agar melakukan pencarian informasi melalui dokumen pula (sumber informasi tercetak). Hal tersebut mungkin tidak mudah, namun dapat dicoba untuk diterapkan. Pencarian informasi tidak hanya secara online, namun juga secara offline, seperti mencari informasi di perpustakaan, sehingga perpustakaan mengetahui kebutuhan informasi masyarakat tuli. Saran lain ditujukan kepada masyarakat dan penyedia jasa informasi hendaknya dapat memahami apa yang dibutuhkan oleh masyarakat tuli. Memiliki sifat ramah dan mengerti keadaan masyarakat tuli dapat dijadikan sebagai salah satu solusi untuk mengetahui kebutuhan mereka sehingga mereka tidak merasa minder karena keterbatasan yang dimiliki.

\section{DAFTAR PUSTAKA}

Akbar, M. T., Martutik, M., \& Safii, M. (2018). Konten Akun Media Sosial Twitter Perpustakaan Universitas Perguruan Tinggi Di Indonesia. BIBLIOTIKA : Jurnal Kajian Perpustakaan dan Informasi, 2(1), 41-49.

Arikunto, S. (2013). ProsedurPenelitian: suatu pendekatan praktik. Jakarta: Rineka Cipta

Creswell, J. W. (2016). Research Design: Pendekatakan Metode Kualitatif, Kuantitatif, dan Campuran. Yogyakarta: Pustaka Pelajar. 
Haryoko, S. (2009). Efektifitas Pemanfaatan Media Audio-Visual sebagai Alternatif Optimalisasi Model Pembelajaran. Jurnal Edukasi@Elektro, (Online), 5 (1): 1-10, (https:/ /scholar.google.co.id/), diakses 30 Juli 2018.

Indranata, I. (2008). Pendekatan Kualitatif untuk Pengendalian Kualitas. Jakarta: UI-Press.

Nicholas, D. (2000). Assessing Information Needs: tools, techniques and concepts for the Internet Age. London: Aslib imi.

Rahmala, I. D., Suwignyo, H., \& Kurniawan, T. (2018). Kemampuan Literasi Informasi Pemustaka Berdasarkaninformation Literacy Standars For Student Learning. BIBLIOTIKA : Jurnal Kajian Perpustakaan dan Informasi, 2(1), 6-12.

Safii, Moh. (2017). Perencanaan Perpustakaan Universitas Mercu Buana(UMB) Cabang Cibubur. JIPI (Jurnal Ilmu Perpustakaan dan Informasi), 2(1), 115-128. https://doi.org/10.30829/jipi.v2i1.925

Safii, Moh. (2019). Redefining The Five Laws of Library Science in the Digital Age. Dipresentasikan pada 2nd Internasional Conference on Culture and Language in Southeast Asia (ICCLAS 2018). https://doi.org/10.2991/icclas-18.2019.7

Safii, Moh, Zen, Z., \& Mayesti, N. (2018). Strategi Perpustakaan Perguruan Tinggi dalam Menerapkan Library 2.0. JIPI (Jurnal Ilmu Perpustakaan dan Informasi), 3(1), 144-159. https://doi.org/10.30829/jipi.v3i1.1660

Safii, Moh. (2015). Mengulas Opac 2.0 Sebagai Next Generation Library Catalog. Jurnal Imu Informasi, Perpustakaan, dan Kearsipan, 16(1). https://doi.org/10.7454/jipk.v16i1.21

Suwarno, W. (2010). Ilmu Perpustakaan \& Kode Etik Pustakawan. Jogjakarta: Ar-Ruzz Media.

Wilson, T.D. (2000). Human Information Behavior. Informing Science, (Online), 3 (2): 49-55, (https://pdfs.semanticscholar.org/), diakses 5 Februari 2017. 